\title{
Pavlov in America: A Heterodox Approach to the Study of his Influence
}

\author{
Gabriel Ruiz, Natividad Sánchez, and Luis Gonzalo De la Casa \\ University of Seville
}

\begin{abstract}
This work presents a critical analysis of Pavlov's influence that goes beyond the conventional view: that which reduces his influence in American psychology to the behaviorism of Watson and Hull. In order to understand the nature of the Russian physiologist's influence in American psychology, we propose a distinction between three approaches to it: 1) the symbolic approach, on representing a model of the possibility of constructing an objective psychology; 2) the methodological approach, given the importance of the technique of conditional reflexes; and 3) the theoretical approach, which is derived from his theory of higher nervous activity. This perspective permits us to suggest that most of Pavlov's influence on behaviorism was of a symbolic and methodological nature-though the methodological influence also reached other authors that did not belong to the behaviorist traditions, as was the case of Mateer. As far as the theoretical influence is concerned, our work proposes that it is more visible in authors such as Gantt and Liddell, or even in authors such as Boldirev, Director of the Pavlovian Laboratory at the Battle Creek Sanitarium in Michigan. The case of Gantt is especially interesting because, in addition to his important contributions, he played an essential role in the foundation of the Pavlovian Society, and the journal Conditional Reflex. What our work proposes is that to understand the nature of Pavlov's influence in American psychology it is necessary to take into account the very characteristics of that psychology: its pragmatic interests, its methodological rigor, the dominant systems of neo-behavioral theory and the changes that occurred after the Second World War. Keywords: Pavlov, American psychology, behaviorism
\end{abstract}

\begin{abstract}
En el presente trabajo se realiza un análisis crítico de la influencia de Pavlov que va más allá de su visión convencional: aquélla que reduce su influencia en la psicología americana al conductismo de Watson y Hull. Para entender la naturaleza de la influencia del fisiólogo ruso en la psicología norteamericana proponemos distinguir entre tres sentidos de la misma: 1) el simbólico, al representar un modelo de la posibilidad de construir una psicología objetiva; 2) el metodológico, por la importancia de la técnica de los reflejos condicionales; 3) el teórico, que se deriva de su teoría de la actividad nerviosa superior. Esta perspectiva nos permite sugerir que la mayor parte de la influencia de Pavlov sobre el conductismo fue de carácter simbólico y metodológico, aunque la influencia metodológica también alcanzó a autores que no pertenecieron a las tradiciones conductistas como fue el caso de Mateer. En lo que concierne a la influencia teórica, nuestro trabajo propone que es más visible en autores como Gantt y Liddell, o en otros menos conocidos como Boldirev, director de un laboratorio pavloviano en el Battle Creek Sanitarium de Michigan. El caso de Gantt nos parece de especial interés porque además de sus importantes contribuciones, jugó un papel esencial en la fundación de la Pavlovian Society y de la revista Conditional Reflex. En conclusión, lo que nuestro trabajo propone es que para entender la naturaleza de la influencia de Pavlov en la psicología norteamericana hay que tener muy presentes las propias características de esa psicología: sus intereses pragmáticos, su rigurosidad metodológica, los sistemas teóricos neoconductistas dominantes y los cambios que se fueron produciendo tras la segunda guerra mundial.
\end{abstract}

Palabras clave: Pavlov, psicología americana, conductismo

This work was supported by grant BSO2002-01533 from the Ministry of Science and Technology. Some of the data that appear in this work have been presented in previous reports (Ruiz, Sánchez, \& De la Casa, 2002a; Ruiz, Sánchez, \& De la Casa, 2002b).

The authors would like to offer a special vote of thanks to Dr. Daniel P. Todes, whose suggestions gave us the idea of distinguishing between the different meanings of the term influence as discussed here.

Correspondence concerning this article should be addressed to Gabriel Ruiz, Departamento de Psicología Experimental, C/ Camilo José Cela s/n. 41018 Sevilla. E-mail: gruiz@us.es 
Let us begin by clarifying the meaning of the title we have chosen. For a work of a historical nature such as this, there are different ways of approaching the historiographic study of the problem in question. The least interesting of these would be that which concerns Pavlov's visits to America. As far as we have been able to confirm, Pavlov visited the United States on two occasions. The first of these was in 1923, when, accompanied by his son Vladimir, he toured several cities and institutions (Babkin, 1949, pp. 1067). The second was in 1929, to attend the IX International Congress of Psychology at Yale, and the XXX International Congress of Physiology, at Harvard. It is interesting to note here Pavlov's reply to Langsfeld's invitation to participate in the first of these:

Many thanks for the invitation to the International Psychological Congress. I am finally able to decide the question about my trip to America, but I am not a psychologist. I am not quite sure whether my contribution would be acceptable to psychologists and would be found interesting to them. It is pure physiology-physiology of the functions of the higher nervous system - not psychology. Will you kindly clarify the situation for me? (Paré, 1990, p. 648)

Another, much more serious - and more complex - way of dealing with this question is to assess the influence exercised by the Russian physiologist on the American scientific world, and particularly in the field of psychology. This problem is far from being solved.

To repeat here that Pavlov is one of the great figures in the history of science that has had the most influence on psychology may appear incontestable: Are we not precisely honoring his enormous influence in this volume? Would anyone dare to doubt his contributions amid the celebrations of the centenary of his Madrid Lecture? No one could be blamed for considering the matter closed: Pavlov has had a great influence. All the indications are there (e.g., Coleman, 1988; Hagbloom, Warnick, Warnick, Jones, Yarbrough, Russell et al., 2002).

Even so, what we shall argue in this work is that the meaning of Pavlov's influence on American psychology has not been systematically studied. Or, to put it in a more balanced way, we might say that the problem has been reduced to its simplest form: In some cases it has been denied that Pavlov had any influence at all, and in others, his influence has been taken for granted, but without attempting to assess its nature or scope.

At the root of this matter is the question of the influence itself, understood now as an historiographical problem. What meaning or meanings have been attributed to the term influence in historical studies on psychology? Does the influence of an idea or theory depend exclusively on its scientific value? Or, on the other hand, should the influence of one author on others be conceived as part of another, more general question, which is that of the transference and reception (temporal and/or spatial) of scientific ideas? In the first case, the influence would depend exclusively on the intrinsic value of the idea or theory in question. In the second, the influence would seem to depend not only on this value, but also on the characteristics of the receiving discipline-for example, its options in terms of methodology or its more substantive aspects-, as well as on the specific conditions of the historical point at which the receiving discipline takes that influence on board.

In our view, the question of Pavlov's influence should be divided into, at least, three different components, though all interrelated:

1) The first of these would be the symbolic and/or ideological component, that is, his impact on scientistspsychologists-as a supposed example in relation to the possibility of studying behavior and/or psychology in an objective way. It is likely that the majority of Pavlov's influence on American psychology is of this nature, though for the moment this is only a hypothesis.

2) The second component would be the methodological character, and would refer to the influence of the technique of conditional reflexes. This is probably the component that will be most talked about in this centenary. It was undoubtedly an important influence on behaviorism, though authors from outside this tradition may also have received its influence.

3) Finally, there would be the theoretical component, the influence of conditional reflexes with their associated specific vocabulary and with their set of theoretical conclusions, that is, the theory of higher nervous activity. The influence of this component has quite possibly been scarce outside of Russia.

Before beginning to give examples of the components mentioned above, it is appropriate to point out that the symbolic and methodological components are closely linked to one another, and that they are presented separately in this work only for the purpose of presenting our argument more clearly.

We have just stated that the major part of Pavlov's influence on American psychology would have been of the symbolic type, that is, as a model of objective approach, and there is evidence of this. Thus, for example, in the first work that referred to the research of Pavlov (Yerkes \& Morgulis, 1909), and in the work of Watson, himself discussing the place of the conditioned reflex in psychology (Watson, 1916), emphasis was placed on the fact that conditional reflexes could be a substitute for introspection, and therefore, a more objective method. There is no allusion to the theoretical aspects of Pavlov's research in the work of Watson, who even expressed his preference for Bechterev's motor preparation, and considered the salivary reflex to be of limited applicability and utility.

Many years later, in 1955, Spence, the star pupil of Hull, was invited to deliver Yale's most prestigious lecture course: the "Benjamin Silliman Memorial Lectures." Spence took 
advantage of the occasion to present his theory of learning and conditioning, and began with a historical presentation of the discipline. In the written text of the lectures, Spence offers his historical view in the first chapter, to which he gives the title "Historical and Modern Concepts of Psychology." The fact that Spence does not mention Pavlov there is of great interest in relation to the issue we are dealing with in the present work. We should bear in mind, moreover, that Spence (1956) had written in the preface to his book: "Essentially this research and its accompanying theory represent an extension of pioneering work in the area of the conditioned reflex of Pavlov in Russia and of Hull in this country" ( p. vi).

A final example is related to Skinner, one of the American psychologists that most disagreed with Pavlov. We should recall that in his autobiography, Skinner mentions that the first books in his psychology library were Philosophy, by Russell, Behaviorism, by Watson and Conditioned Reflexes, by Pavlov. His principal work, The Behavior of Organisms: An Experimental Analysis (Skinner, 1938), constitutes a good example of the symbolic components - no author is cited as often as Pavlov-and the methodological ones-the emphasis Skinner placed on control is a clearly Pavlovian legacy. Skinner's veneration for Pavlov was also visible at a more domestic level. Thus, Skinner, a psychologist who was not wont to express unconditional admiration for anyone, and who has so often been described as being opposed to physiological studies, had a photograph of Pavlov on the wall of his office throughout his entire academic life — a photograph which, after his retirement from Harvard, he hung in the study at home, along with those of his family and of his friend Keller (Catania \& Laties, 1999).

The second type of influence to which I referred above was of a more methodological nature. This form of interpreting the influence of Pavlov can be found in many of the contributions to this special issue (see Aguado, Mackintosh and Rescorla in this issue). This form of analyzing the contemporary influence of Pavlov circumscribes it to a particular aspect of his work: the conditioning we refer to today as Pavlovian. The significance of the technique is beyond doubt, even though salivary conditioning has rarely been used by psychologists. What is remarkable in this case, at least from a historical point of view, is that this type of influence has dissociated two things, that in the work of Pavlov, have become inseparably linked: the technique of conditional reflexes and the theory of higher nervous activity. A good example of this can be found in the first work that Hull wrote on the theory of learning. In that work, Hull concentrated on the functional aspects of the conditional reflex, and avoided touching on the physiological aspects of Pavlov's theory (Hull, 1929).

The methodological influence was key for the development of behaviorism, as its theoretical vocabulary became replete with terms emerging from Pavlov's laboratory. Nevertheless, this process of linguistic importation did not signify the acceptance of the Russian's theoretical points of view. The technique of conditional reflexes was accepted not for its values in the clarification of the nervous processes occurring in the large hemispheres, but rather for its importance in making an objective explanation of learning processes possible.

Another interesting example of this methodological influence can be found in Mateer, one of Burnham's students. Burnham had been one of the founders of the mental hygiene movement at the beginning of the twentieth century, and a Professor of Educational Psychology and School Hygiene at Clark University. In 1916, Mateer wrote her doctoral thesis under the direction of Burnham, entitled, Child Behavior: A Critical and Experimental Study of Young Children by the Method of Conditioned Reflexes (Mateer, 1918). This is an original and little-known work in which Mateer succeeded in replicating the experiments carried out with children by Krasnogorski, one of Pavlov's students. But it was no mere replication of that work: Mateer improved the technique of conditioning and correlated her results with other measures, such as age, sex, and intelligence, in two samples of children: normal and mentally retarded (Windholz \& Lamal, 1986).

Mateer's experiments with children were carried out between 1914 and 1916. The procedure she used for establishing the conditional reflex was quite ingenious. The boy or girl's eyes were covered with a bandage, the conditional stimulus, for twenty seconds. At eleven seconds they were given a piece of chocolate, and the bandage was removed as soon as the twenty seconds had elapsed. After three minutes, the trial was repeated. During this interval, she administered different intelligence tests to the children and took anthropometrical measures. Mateer (1918) recorded chemographically the movements of mastication and swallowing provoked by the chocolate, and wrote the following: "The child was considered to have learned to associate the bandage with the feeding of chocolate when he twice in succession opened his mouth for the chocolate before the ten seconds preceding the stimulation by chocolate had elapsed" ( pp. 98-99).

Mateer used two samples of boys and girls, normal and retarded. There were 67 children in total, with ages ranging from twelve months to seven years. Her experiments showed the formation, retention, inhibition (extinction) and reconditioning of the conditional response. Some of her results revealed that, for example, the children in the normal group learned the association rapidly ( 3 to 9 trials), even if this number depended on age (as age increased, mean number of trials decreased) and sex (under age two, boys learned more rapidly; over two years of age it was the girls that were quicker). In boys and girls of the same age, Mateer found a positive correlation between the results on the Binet and Yerkes scales and the speed with which the conditional response was learned. Finally, the main difference she found 
between the two samples of subjects was related to the number of trials necessary for the development of inhibition: only $42 \%$ of the children from the retarded group inhibited the conditional response in a number of trials that fell within the range of performance observed in the normal group.

Thus, studies such as Mateer's introduce into the historical investigation of psychological data that conflict with the classic interpretation of Pavlov's influence, which is based exclusively on the well-known binomial "Pavlov-behaviorism" (Boakes, this issue; Ruiz, Sánchez, \& De la Casa, 2002b).

We shall now concentrate on the third type of Pavlov's influence and the most theoretical, his theory of higher nervous activity. Let us begin by recognizing that this is probably the type of influence that has been least commonly found outside of Russia. One of Pavlov's students, Frolov (1937), referred to this matter shortly after the death of his mentor; after mentioning various names and countries. In regards to America he said:

At the present time, experiments using the method of conditioned reflexes are being performed in the following laboratories: USA: Ithaca (New York State)- Cornell University. The work of Liddel and his collaborators. Baltimore (Maryland)- The Laboratory for conditioned reflexes belonging to Adolf Meyer's Psychiatric Clinic. The work of W. Gantt and his collaborators. Some of the collaborators of Liddell and Gantt are now undertaking independent work by the same method. (pp. 280-1)

Babkin, author of one of the biographies about Pavlov, quoted a letter from Lashley in which the American psychologist spoke about Pavlov's influence:

[Although Pavlov] pointed the way to fundamental investigation on the physiology of the brain ... this way, unfortunately, was not followed systematically in America and very little was added to further analysis of the cerebral functions with the help of this method(*). Paradoxically, many psychologists, in whose current works the influence of Pavlov's theories can be most clearly traced, have turned to the development of conceptual nervous systems from which all neurological interpretations are rigorously excluded. Thus the chief influence, on psychology in America, of conditionedreflex theory seems to have been diametrically opposed to Pavlov's expectation of using his studies as a basis for the physiological explanation of behavior ... (Letter from Lashley to Babkin, 1946; cit. in Babkin, 1949, p. 322)

Apart from the special relevance of the letter to the issue we are dealing with here, there is also an interesting footnote added by Babkin himself and referenced in the text by the asterisk: "(*) We must not forget the work of Gantt, Dworkin, and Liddell" (Babkin, 1949, in footnote 3, p. 344).

This opens up a new perspective on the problem of Pavlov's influence, that in no way reduced his reception by behaviorism, and which has to do not only with the symbolic and methodological components, but also with the theoretical aspects of his work. We have just seen how the names of Liddell and Gantt were presented by disciples of Pavlov as followers in America of the Russian's work. However, the theoretical component is also present in other disciplines related to ours or in certain conceptual domains of psychology itself. From this perspective, the theoretical influence of Pavlov would have made its presence known in areas as apparently disparate as those of cyberneticsAshby (1952), Walter (1953) and Wiener (1948) — and early electroencephalography (Walter, 1953), as well as in the psychology of personality (Eysenck, 1957; 1967; Gray, 1964; Strelau, 1972), and psychiatry (Astrup, 1965; Salter, 1961).

Thus, now that the historiographical problem of Pavlov's influence has been more clearly outlined, and that the nature of this issue appears more complex than might initially have been suspected, we shall move on to consider two of the historical figures mentioned above, Gantt and Liddell, whom we consider to be representative of what we might call, sensu strictu, "Pavlovians in America" (Ruiz, Sánchez, \& De la Casa, 2002a).

\section{Gantt and Liddell}

Gantt (1892-1980) received his Bachelor of Science degree from the University of North Carolina, majoring in psychology and philosophy, and obtained his MD from the University of Virginia in 1920. In 1922, Gantt set sail for Petrograd (Leningrad), as part of the American Relief Administration, which provided medical aid to Russian citizens in the wake of the First World War. Gantt worked in Pavlov's laboratory between 1925 and 1929. In 1929, Meyer brought him to Johns Hopkins as director of the Pavlovian Laboratory, which Meyer had set up with the aid of the Rockefeller Foundation, and which Gantt presided over until his retirement in 1958. His work in charge of that laboratory, his translations of Pavlov's main works and those of many other Russian authors (Luria and Bykov, among others) and his role as founder of The Pavlovian Society and the journal Conditional Reflex, make him the focus of attention in our article.

Gantt's career was littered with distinctions: In 1946 he received the Lasker Prize for his book Experimental Basis for Neurotic Behavior. Origin and Development of Artificially Produced Disturbances of Behavior in Dogs, published in 1944; in 1950 he was awarded the American Cardiological Association Prize for his research on the cardiovascular conditional reflex and hypertension; in 1970 he won the Nobel Prize for Physiology and Medicine; in 1972 he received the Gold Medal from the Society of Biological Psychiatry; and in 1975 he was awarded the van Giesen prize by the Psychiatric Institute of New York and the Purkinje Medical Society (Heaton, 1986). 
Liddell (1895-1962), graduated from the University of Michigan and was awarded his doctorate at Cornell, the university at which he spent the rest of his academic life. He founded and directed the Behavior Farm Laboratory, which after his death was re-named the Liddell Laboratory of Comparative and Physiological Psychology. To Liddell goes the honor of having set up, in 1924, the first American laboratory of conditional reflexes (Liddell, 1926).

Liddell had begun as an assistant to Simpson in 1922. Simpson was interested in endocrinological research, and gave Liddell the task of experimentally analyzing the functions of the thyroid in development, heart rate, body temperature, activity and ability to learn simple tasks (e.g., mazes). If cretinism was a symptom of serious alterations of thyroid functioning, Simpson and Liddell hoped to find evidence of alterations in learning after removal of the gland. However, the maze was not convincing as a sensitive procedure. Reading Pavlov's Huxley Lecture, published in The Lancet (Pavlov, 1906), and a stroke of luck-Anrep was in New York giving a course of lectures on conditioned reflexes in the spring of 1923, convinced Liddell of the potential of the Pavlovian technique. From that time on, Liddell began a research program, of a markedly comparative nature, using the technique of conditional reflexes. Gantt and Liddell, and their respective laboratories, maintained a close relationship that began in the summer of 1926, when Liddell visited Leningrad and met Gantt in Pavlov's laboratory (Liddell, 1956).

\section{Methodological Attitudes and Conceptual Contributions}

In what follows, we shall summarize the aspects that make these authors unique. With our ultimate purpose of this article in mind, two points should be made. The first concerns the historical situation of American psychology in the period in which Gantt and Liddell began to make their contributions: the 1930s, a decade marked by the rise of neo-Behaviorism. The second is that the contributions of Gantt seem to us, from the historical point of view, to be of more relevance than those of Liddell. Thus, this section will be organized according to the contributions of the former, with the latter appearing when his presence has historical significance.

As far as methodological aspects are concerned, both men were fervent advocates of the single-case study. Pavlov had always maintained a critical attitude towards the methodology of the "one-off" physiological experiment customarily employed by his contemporaries (see Todes, 2002, pp. 84 onwards). In contrast, he preferred long term preparation: the study of the subject over long periods of time. It is not surprising, then, that Gantt and Liddell continued these methodological traditions. Indeed, one of the most notable examples is constituted by the case of three dogs, "Nick," "Fritz," and "Peter," which Gantt studied for 12 years (Gantt, 1944).
As we might expect, from this type of approach there derived a highly critical disposition with regard to statistical inference:

Of more importance than the classification into groups, even with the most closely correlated characteristics, is the thorough study of the individual. The large number of possible combinations of factors of susceptibility make the study of the individual more revealing than the statistical summary based on an average of a given characteristic in many individuals correlated with an average of the results of stress in many different individuals. The variations are often more important than the average. (p. 176-7)

Clearly, when the time window of the study transcends the limits of the experimental session(s) and impinges on the life of the individual, then aspects related to individual differences, social factors or the very internal dynamic of the processes studied take on significance. These issues, which had such specific weight in the work of these authors, as we shall see below, aroused little interest in many of the behaviorists advocating the approach of Pavlov:

The material of this monograph has been obtained by the intensive, prolonged and comparative study of a few individuals rather than by subjecting large numbers of animals to a set procedure. By this method we are able to see individual differences. And, though we are unable to state what per cent of animals break down or what happens in the total population, we get a clear picture of what may happen to individuals.

A large number of animals is desirable when we want to rule out individual variations. But in a study such as this, the individual is one of the important factors, and an average with other animals in a large group would tend to obscure just the thing we wish to observe. It is the detailed and controlled study of each dog separately, and not the statistical average that reveals the mechanism of the disturbance; a statistical summary and average in such studies would tend to eliminate just those personality differences that we wish to see... (Gantt, 1944, p. 178)

What were the conceptual contributions of Gantt? Ban and McGuigan (1987) and Harvey (1995) have systematized some of these contributions.

One category of studies would be related to the role played by the components of the reflex arc in the establishment of a conditional reflex. Gantt's research led him to conclude that the activation of the efferent peripheral routes of the conditional reflex was not a necessary condition for its formation. However, he demonstrated that it was possible to establish a conditional reflex by pairing an auditory conditional stimulus with direct stimulation of the brain tissue (Brogden $\&$ Gantt, 1942). These studies led Gantt to propose the term centrokinesis to refer to the fact that the stimulation of isolated organs with no afferent entrance to the central nervous system, cannot give rise to the formation of a conditional reflex. Conditional responses require the entering stimulus to reach 
the central nervous system. This is a concept that extends the Pavlovian concept of "analyzer" (Wolf, 1987).

One of the most relevant aspects of Gantt's work revolves around the conditioning of visceral systems. Gantt measured the cardio-respiratory changes accompanying food-related conditional reflexes, finding that, while heart rate was more easily conditioned, this conditioning was also more difficult to extinguish than the salivary response. These studies, in which the activity of different systems was registered simultaneously, allowed him to demonstrate the existence of a disharmony between the different components of the conditional reflex. Gantt (1953) coined the term schizokinesis to refer to this dissociation, and considered it as an innate discordance between general emotional responses, such as heart rate, and other types of response, such as salivary secretion: "the inherent conflict between the general emotional responses and the more perfectly adaptive (schizokinesis)...” (p. 162).

In the course of these observations on the conditioning of visceral systems, Gantt embarked on a systematic study to replicate the conditioning of the renal functions that Bykov had obtained (1957). After many failed attempts, Gantt concluded that these functions could not be conditioned, and coined the term "organ-system responsibility" to refer to those situations in which conditioning lacked adaptive value or, as in the case in question, notably reduced the possibility of survival. In such cases, conditioning would not be appropriate. This led him to question the work of Miller that demonstrated the possibility of conditioning these renal functions (Gantt, 1972; Livingston \& Gantt, 1968; Miller \& Dicara, 1967).

Faced with the evidence of these results that revealed the limitations of conditioning, Gantt (1982) stated that the conditional reflex could never run counter to homeostasis: "the formation of a conditional reflex in greater or lesser degree is in relation to the physiological function of the system upon which it is operating; a conditional reflex appears impossible too, for it would violate radically the function performed by this system in the body economy, thus opposing the principle of homeostasis" (p. 121).

Earlier, we mentioned some studies carried out by Gantt on three dogs over a period of twelve years (Gantt, 1944). In these studies, one of the animals, Nick, received discriminative training that produced the characteristic neurotic symptoms that Pavlov had already observed in his studies. But the most significant result of this study was that Nick continued to show these nervous symptoms for 10 years, even though there was no further presentation of the conflictive experimental situation that originally triggered them. Moreover, as Gantt (1970b) wrote:

It is remarkable in Nick not only that the nervous symptoms continued for 10 years without repeating the original conflict, but that the spread to the urinary and sexual systems did not occur till after 1935, several years after the conflict. That they were related to the conflict is shown by their appearance only in the experimental environment ... (p. 320)
Gantt used the term "autokinesis" to refer to the process of internal development that may result in the appearance of new symptoms, even many years after experiencing the situation of pathogenic conditioning. Nevertheless, although Gantt identified this process of internal development that may be responsible for the propagation and perpetuation of pathological symptoms, the possible mechanisms involved in it have yet to be determined (Corson and O'Leary, 1987; Gantt, 1953).

When we referred above to Gantt's use of single-case designs, we mentioned that these longitudinal studies permitted him to observe aspects related to individual differences and social factors. In this regard, one of the most singular contributions of Gantt is that which refers to what he called the "effect of person." As early as 1936, he had observed that a person could alter the heart rate of a dog simply by entering the same room or stroking the animal. In his 1944 book he made the following observation:

On this day, experiments were done to show the effect of the social factor on anxiety. Although it had been previously noted that the approach of a person who had worked with the dog would often bring on the raucous breathing and other pathological symptoms, conversely we saw that standing close to the animal and more particularly stroking and petting him prevented or dissipated the symptom of anxiety. Thus when I or either of two strangers (H.S., K.) petted the animal there was no reaction to the tone, but the tone tried alone on the same day gave the typical reactions-whining, dyspnea, retreating, erection... ( p. 85)

Many years later, Gantt (1970a) wrote:

The inclusion of cardiovascular measurements in conditional reflexes makes possible the detection of factors not hitherto easily recognized. Such a factor is the effect of one individual on another. This effect is both generic and specific. Thus all human beings when petting the dog ... produce a marked slowing of heart rate, while the mere presence of a person usually accelerates the heart, depending upon the relationship of that particular person to the dog .... This effect may be specially marked in pathological animals ... ( p. 88)

It is not unreasonable to state that this effect of person has important implications for clinical practice in general and psychotherapy in particular. Nevertheless, these implications have still not been studied in a sufficiently rigorous manner (Lynch, 1987).

To conclude this section, we should mention another significant contribution of Gantt; that which refers to the early detection of the propensity to mental illness (Gantt, 1959). How could this objective be achieved? Gantt proposed methods for the detection of predisposition to crisis. His plans were based on the study of conditional reflex behavior during childhood. The introduction of mild stress while the child was solving discriminative tasks made it possible to measure 
the extent and duration of the resulting disorder in relation to the motor, cardiovascular and respiratory functions.

Centrokinesis, schizokinesis, autokinesis, organ-system responsibility, effect of person-these constitute a set of terms that Gantt derived from his studies on conditional reflexes. In our view, it could be said that the empirical basis of all of them would be found in the studies related to "experimental neurosis" (Gantt, 1944, 1953). In those works, Gantt, and also Liddell, discovered new etiological factors that Pavlov had not taken into account. Thus, for example, Liddell (1953) emphasized the predominance of emotional factors over cognitive ones in the onset of these disorders, and the importance of the vigilance reaction in the origin of these perturbations:

We shall not understand the dynamics of the experimental neurosis if we think of positive and negative conditioning in cognitive terms, similar to those employed in explaining the dispassionate judgments of the subject in the psychophysical experiments.... It is the raw force of this primitive sentinel reaction, which I spoke of earlier as the emotional undertow of behavior. Through its action, the delicately adaptive performances may be completely inundated or submerged, as in cases of panic during fire or shipwreck. (pp. 166 and 169)

Meanwhile, Gantt (1953) stressed the individuals temperament:

My investigation of experimental neuroses emphasizes that other important factors are present besides that of the difficult differentiation, which was discovered by Pavlov. First is the innate susceptibility of the individual to breakdown, and second are many details of the environmental stress situation, especially including the individuals concerned in the experimentation. The development of the neurotic breakdown may occur in both space and time; i.e., it may spread to many physiological systems apparently not involved at first, and the spread may continue for a number of years after the original conflicting situation has been removed. (p. 162)

The issue of "experimental neurosis" is one that merits a detailed historical analysis. In our opinion, what is most interesting, in relation to this matter, is the opportunity offered to the historian to study a fairly well-defined conceptual domain, which emerged and disappeared within a relatively specific period, the 1940s and 50s, and which involved authors from different traditions and different disciplines, such as Gantt, Dollard, Liddell, Maier, Miller, Masserman, Mowrer, Wolpe, and so on. This is another indication of the "transversality" of Pavlov's influence on American psychology.

The 1950s: the Pavlovians become established

In May, 1955, Gantt founded the Pavlovian Society of North America (which later changed its name to the
Pavlovian Society). Gantt himself recounts the events in an interview by some of his students in 1972:

Liddell and Kempf, and especially Liddell and I, wanted to form a group of people to meet and discuss conditional reflexes. There was no such society in this country at that time, nor was there any kind of forum for what Liddell and I were doing. And so we got together to start a group .... There were just a few people who were doing that specific kind of work at that time. Then, later I had the idea of expanding it and making it interdisciplinary to include people from several domains of interest, to make a kind of a balance in the society and keep it to small numbers: 125-150 domestic members among groups chosen from internal medicine, cardiology, physiology, psychology, and with some other people from other disciplines. (Reese, Peters, \& Dykman, 1987, p. 35)

The first scientific meeting of this Society took place in that year, at Liddell's laboratory in Ithaca, as an act of recognition of his veteran status in research on conditional reflexes. Gantt asked Reese, Kempf, Rioch and Liddell himself to form part of the executive committee of the Society.

Gantt wished to create an interdisciplinary society in which physiologists, neurologists, psychologists and psychiatrists would meet and discuss as equals, even though he had expressed on more than one occasion a certain mistrust of experimental psychology. As the Society's president, Furedy (2001), recently told its members:

[Gantt] did not want "too many (experimental) psychologists" in the society .... Like many prejudices, this one of Gantt's had a grain of truth, especially during those times when most experimental psychologists tended to be quite insular in their theorizing. Recall that at this time Skinner and his followers actually advised psychologists not only to eschew organismic psychological explanations, but also any reference to physiological functions. And even in the Hull-Tolman groups, physiological psychologists like Miller were quite rare. (p. 9)

Liddell (1953) was similarly critical: "Behavior theory is, I suspect, cluttered up with gimmicks. Pavlov's 'newly formed nervous pathway' is a gimmick and so, I believe, is Freud's 'libido'. In my opinion, 'tissue needs', 'need-reduction', many of the postulates, theorems and their corollaries, together with the formal nerve nets of contemporary psychology, partake of the nature of conceptual gimmicks" (p. 170).

Some years passed before the society was able to make use of a periodical publication to channel all the research carried out. In 1965, Gantt founded the journal Conditional Reflex (1966-1973), which subsequently changed its name to The Pavlovian Journal of Biological Science (1974-1990), coinciding with the appointment of McGuigan as editor, and more recently was changed again to Integrative Physiological and Behavioral Science (from 1991 to the present), under the editorship of Wolf. 
Both the society and the journal, at least during their early years, were practically dominated by Gantt. This group of Pavlovians, so critical of the experimental psychology of their time and so distanced from the methodological standards and statistical analysis prevailing in it, were almost obliged to organize themselves institutionally. Quite similar reasons were put forward by the Skinnerians for founding their society (1957) and their journal (1958) (Laties, 1987).

This process of institutionalization initiated by Gantt coincided in time with a loss of power for academic psychologists within the American Psychological Association (APA) ${ }^{1}$. An indication of this was the attempt by Spence and Graham in 1948, shortly after the APA set up its divisions, to take Division 3 (Experimental Psychology) out of the Association. Although that attempt was fruitless, some years later Spence was involved in a second and more ambitious attempt that was finally successful. The result was the foundation, in 1959, of the Psychonomic Society (Dewsbury \& Bolles, 1995).

It is interesting to analyze the nature of the interactions between the two societies, if indeed there were any. It is worth mentioning that Brodgen, who had worked in Gantt's laboratory from 1936 to 1939 , was a member of the organizing committee of the Psychonomic Society.

Gantt also played an active part in the creation of other markedly Pavlovian associations, such as the Collegium Internationale Activitatis Nervosae Superioris (CIANS), founded in 1960.

The CIANS also publishes a journal, Activitatis Nervosa Superior, founded in 1959, and which, since 1991 has been called Homeostasis in Health and Disease.

\section{New York, October 1960}

October 13th, 14th and 15th of 1960 saw the celebration, at the New York Academy of Sciences, of the Pavlovian Conference on Higher Nervous Activity. Kline and Razran chaired the meeting. Those who attended the sessions, as well as the content of the proceedings, were highly representative of the Pavlovian traditions we wish to put into historical perspective in this work (Kline, 1960).

Both Liddell and Gantt played a leading role, together with a large group of researchers from neuroanatomy, neurophysiology, psychiatry and psychology. The only psychologist that participated as a speaker was Miller. Solomon, Spence and Kimble intervened in the discussions. Razran also participated in them, but this was not his only role, as he was acting as vice-president of the event, together with the prestigious psychiatrist Kline.

The interventions of the American psychologists are of great interest, since they are highly indicative of the type of discrepancy prevailing between the methodological and theoretical influence of Pavlov in the neo-Behaviorist approach, and which we already mentioned at the beginning of this article. Thus, for example, in Solomon's intervention we can see clearly how the theoretical interpretation of the phenomena of conditioning operates on a different level to that of higher nervous activity, specifically in the framework of the Two Processes theory. In phrases such as the following, Solomon himself underlines the difference between the American and Pavlovian approaches: "In the Pavlovian conditioning laboratory, phenomena very often are looked at very differently than they are in the American tradition, which is typically Thorndikian and involves, whether we like it or not, concepts such as motivation, drive, and reward" (Kline, 1960, p. 1065).

However, it was in Spence's intervention that many of the aspects discussed here were most clearly explained. The importance of this text justifies an extensive quotation from it:

As a psychologist whose special field of interests lies solely in behavioral phenomena and not in its neurophysiological basis, I find myself unable to comment in any specific manner on the research studies presented in these pages. Instead, I should like to record a brief methodological note concerning the influence that the man we honor on this occasion, I. P. Pavlov, had upon the development of modern objective psychology in the United States. More particularly, I should like to call attention to the important role that the writings of Pavlov played in the behavior theory approach to simple learning phenomena, including conditioning, developed at Yale University, New Haven, Conn., by Clark Hull and those of us allied with him.

The Pavlovian influence upon our work was such, in fact, that the late Karl Lashley a number of years ago, fell into the habit of designating Hull, myself, and others of our group as neo-Pavlovians. While I am sure that Hull felt, and I know that I did, that the designation was a great compliment, I have always had serious reservations about it: first, as to whether

\footnotetext{
1 The following anecdote, recounted by Skinner in his autobiography, illustrates perfectly the nature of the changes taking place in the APA. In reference to the APA's presidential elections, Skinner writes: "I have discussed the matter with Keneth Spence and Neal Miller, who were also disturbed by the way in which the election were conducted, and Ken joined me in deciding not to run. In 1964, however, his name was on the ballot and in late July he wrote to explain why he had changed his mind: he had wanted to prove that an experimental psychologist could not be elected. I replied that I hated to disillusion him, but I was sure he would win. 'My own reason for not running has always been that I was afraid I would also. I am interested in no more than five percent of the activities of the Association, and I have no inclination to become familiar with the other ninety-five'. Ken proved his point; he was not elected" (Skinner, 1983, p. 287).
} 
Table 1

Pavlovian Conference on Higher Nervous Activity (October 13-15, 1960)

\begin{tabular}{|c|c|c|c|}
\hline & Introductory Remarks & Authors & Discussants \\
\hline \multirow[t]{5}{*}{ Structure and Function } & & Magoun & Pribram \\
\hline & & Miller & Galambos \\
\hline & & Purpura & Anokhin \\
\hline & & Morrell & Magoun \\
\hline & & Grundfest & Kupalov \\
\hline \multirow[t]{5}{*}{ Cortico-subcortical Interaction } & Fremont-Smith & Anokhin & Jasper \\
\hline & & Doty & Majkowski \\
\hline & & Clynes & Mettler \\
\hline & & & Himwich \\
\hline & & & Anokhin \\
\hline \multirow[t]{10}{*}{ Deviance and Drugs } & & Liddell & Grundfest \\
\hline & & Zakusov & Zakusov \\
\hline & & Marrazzi & Miller \\
\hline & & Kline & Killam \\
\hline & & & Marazzi \\
\hline & & & Lehman \\
\hline & & & Kerbikov \\
\hline & & & Lebensohn \\
\hline & & & Lasagna \\
\hline & & & Kline \\
\hline \multirow[t]{4}{*}{ Irradiation and Generalization } & & Kupalov & Kupalov \\
\hline & & Brazier & Solomon \\
\hline & & & Heath \\
\hline & & & Razran \\
\hline \multirow[t]{7}{*}{ Psychopharmachology } & Gantt & Snezhnevsky & Lehman \\
\hline & & Kerbikov & Lasagna \\
\hline & & Heath & Snezhnevsky \\
\hline & & & Kline \\
\hline & & & Simpson \\
\hline & & & Metller \\
\hline & & & $\begin{array}{c}\text { Callaway III } \\
\text { Kerbikov }\end{array}$ \\
\hline \multirow[t]{3}{*}{ Inhibition } & & Asratyan & Spence \\
\hline & & John et. al. & Kimble \\
\hline & & Callaway III & Pribram \\
\hline
\end{tabular}

Lashley intended the designation to be complimentary and, second, whether, whatever Lashley's intention, Hull and I really deserved the label and, if we did, in what sense.

.... It is certainly true that in turning his attention in 1929 to the area of learning, Hull was greatly influenced by the timely G. V. Anrep translation of Pavlov's Petrograd Lectures on Conditioned Reflexes .... However, whereas the interest of Pavlov and his colleagues in these experiments was in the knowledge they might provide as to the nature of the activity of the central nervous system, particularly its higher cortical divisions, Hull's and my interests were in the laws of conditioned behavior per se.

At any rate, on the basis of the empirical laws obtained in these conditioning studies we attempted to develop a theoretical schema consisting primarily of abstractive concepts, the socalled intervening variables, familiar examples of which are habit strength $(\mathrm{H})$, drive strength (D), excitatory potential (E); and inhibition .... 
The question naturally arises as to what the relation of these concepts abstracted from behavioral data is to neurophysiological concepts or processes. Hull, it will be recalled, was fond of attempting to make such tie-ups. Thus he related his concept of habit strength $(\mathrm{H})$ to the strength or degree of conductance of a receptor-effector connection. Actually, however, Hull made little or no use of such coordination in his research program, apparently suggesting them merely as hints or guides to interested physiological psychologists. In contrast to Hull, I have never had a strong compulsion to engage in such thinking, ... I have not attempted to relate systematically our intervening variables to possible neural processes or events and, with my lack of up-to-date knowledge on such matters, I am hardly in a position to state whether attempts at such coordination are at present fruitful or even feasible... (Kline, 1960, pp. 1187-1189)

As we are sure the reader will agree, these extracts speak for themselves.

\section{Final remarks}

The fact that Pavlov has influenced American psychology and psychiatry is beyond all doubt, even after such a critical approach as that presented here. What we are questioning, however, is the classic way of interpreting his influence, that which has reduced it to its reception by the behaviorism of Watson and of Hull. If what is meant by this "inherited view" is that which we have described as the symbolic and methodological components of his influence, then we could not agree more. Quite another matter, as we saw above, is the question of his theoretical influence.

After Watson's presidential address, published in 1916, the conditional reflex began to appear in American textbooks, even though very few psychologists published experimental work on conditioning. Apart from the experiments of Mateer referred to above, Lashley developed a method for registering the salivary response in humans (Lashley, 1916a, 1916b), though he was extremely critical of conditioning studies in his 1929 book. Hamel (1919), using a motor preparation, concluded that conditioned reflexes in man were a reaction dependent on consciousness, and therefore, somewhat different from true reflexes. Cason successfully conditioned the papillary light and palpebral reflexes (Cason, 1922a, 1922b). Schlosberg conditioned the human patellar reflex (Schlosberg, 1928), and Hilgard carried out research on the conditioning of the palpebral response (e.g., Hilgard, 1933a, 1933b).

However, the theoretical impetus received by American psychology, more than Pavlovian, was "Thorndikian;" it was more concerned with motor activity and the consequences of behavior than with glandular responses, and, above all, there was a quest for explanations in terms of connections between stimuli and responses, more than an appeal to nervous processes occurring in what Pavlov had called "large hemispheres."
From the perspective proposed in this article, the term "Pavlovian," now as a historiographical category, appears to better characterize authors such as Gantt and Liddell than others, such as Watson or Hull. There is in the former, a systematic view of the organism, which is lacking in the latter. The subject is conceived as a unit that results from the coordinated activity of the different physiological systems of which it is made up, thanks to the action of the nervous system. Let us recall that Gantt took measures from different systems (glandular, motor, cardiac, etc.), which permitted him to talk about concepts such as schizokinesis, referring to the existence of a disharmony in the activity of some of them.

In addition to Gantt and Liddell, some of Pavlov's collaborators settled in America and founded laboratories. Such was the case, for example, of Boldirev and Babkin. Boldirev set up a Pavlovian laboratory in 1922 at the Battle Creek Sanitarium and Hospital Clinic in Michigan. This laboratory, after Pavlov's visit in 1923, was called the Pavlov Physiological Institute (anonymous, 1929). Babkin was Professor of Physiology at McGill University from 1928 until 1942, and carried out important work on glandular secretions and the nervous system, though he is better known among psychologists for having written a biography of Pavlov (Babkin, 1949).

We might also refer to other authors, such as Razran, whom we mentioned earlier, who for many years was one of the main disseminators of Soviet literature, and who kept a fair distance from the corridors of power of the Pavlovian Society founded by Gantt. The list could even be further extended if we were to take into account not just the USA but also Latin America. In such case we would have to reserve special mention for Álvarez-Buylla, originally from Asturias in northern Spain, and who, like so many others, began a life of exile after the Spanish Civil War. ÁlvarezBuylla had left Spain for the Soviet Union when he was very young. He studied medicine at the University of Rostov, and wrote his doctorate under the direction of Anokhin. In 1947, Álvarez-Buylla arrived in Mexico, where he did some outstanding research, first at the Escuela Nacional de Ciencias Biológicas and the Centro de Investigación y Estudios Avanzados of the Instituto Politécnico Nacional, and later at the Centro de Investigaciones Biomédicas in the University of Colima (Fernández Guardiola, 1997; Giral, 1994). He was the true pioneer of the introduction of conditioned reflexes in Mexico, and demonstrated, using Pavlovian procedures, that the central nervous system intervenes in the compensatory mechanisms that come into play on the activation of chemoreceptors due to lack of oxygen or glucose (Álvarez-Buylla, 1950; Álvarez-Buylla \& Carrasco-Zanini, 1960).

While underlying the historical presence of authors such as Gantt or Liddell when considering the influence of Pavlov in American psychology, we must not neglect to acknowledge at the same time an obvious fact: These Pavlovians moved on the periphery of the dominant neo- 
Behaviorist currents in American psychology at that time. This marginality was quite probably the consequence of a constellation of methodological, theoretical and even personal features. We have already mentioned the interest of these authors in single-case designs, in longitudinal studies; this clinical approach, accompanied by the interest Gantt had shown in differences between individuals, distanced him from the principal methodological perspectives in psychology at the time. Gantt (1944) himself put it this way in his book about experimental neuroses in dogs:

In order to study the susceptibility of the individual I have made use of two lines of information; first, observation of all the natural vicissitudes in the animal's life and environment such as is outlined in the dynamic life chart of Adolf Meyer; second, placing the animal in a position of natural or artificial stress or conflict and noting his reaction and susceptibility measured in as many physiological systems as possible. ( p. 171)

If to all of this we add his unique personal features, such as his scant concern for publishing quickly, we have the impression that Gantt was a figure of another era, a scientist of the nineteenth century, quite removed from the publish or perish stereotype so characteristic of the American scientific community after the Second World War. One of his collaborators recounts an interesting anecdote in this regard:

I chose to study the effect of unconditional stimulus intensity on heart rate conditional response (CR); duplicating work Dr. Gantt had done earlier on the salivary CR. When I completed this project, I turned the paper over to Dr. Gantt for review. He read it, made some minor editorial changes, and sent it on to Dr. John Whitehorn, current head of the Phipps Psychiatric Clinic. When after six weeks I had heard nothing, I asked Dr. Gantt about the paper, implying that I should like to get it off for publication. His response was: 'Don't worry about the paper. If the work is worthwhile it will be valuable whenever it is published. Dr. Adolph Meyer, then head of the Phipps Clinic, sat on my first paper for some five years before sending it back with a note saying that I could submit it for publication. I never bothered to ask him about the paper and believe that he didn't care much for it'... (Reese, Peters, \& Dykman, 1987, p. 53)

However, the clash between Gantt and the psychology of his time may also be a result of the perceptions of psychologists themselves towards the theoretical proposals of these authors which, as suggested in the text by Spence quoted above, may be seen in terms of reductionist assumptions. For a physiologist such as Gantt, interested in the study of the complete, "brainy" organism, the encounter with psychological aspects is inevitable. The problems it raises are of a quite different nature from those that the encounter with the brain, with encephalic physiology, presented for any psychologist of that time, such as Spence. It is not inappropriate to recall here that this matter was indeed dealt with by Pavlov in his Madrid lecture.
In sum, the influence of Pavlov in American psychology is not only the product of the importance of his work, or of some aspects of it: It is also, or above all, a consequence of the very characteristics of that psychology, already established in a tradition with an interest in learning, into which Pavlov's work was incorporated mainly as a model of objectivity and as a demonstration of the feasibility of Watson's old desire to make psychology a true natural science.

\section{References}

Aguado, L. (This issue). Neuroscience of Pavlovian conditioning: A brief review.

Álvarez-Buylla, R. (1950). Descripción de una cámara para el estudio de los reflejos condicionados construida en la Escuela Nacional de Ciencias Biológicas del I. P. N. Ciencia, 10, 291-294.

Álvarez-Buylla, R., \& Carrasco-Zanini, J. (1960). A conditioned reflex which reproduces the hypoglycemic effect of insulin. Acta Physiologica Latinoamericana, 10, 153-158.

Anonymous (1929). A summary of the work of the Pavlov Physiological Institute of the Battle Creek Sanitarium during its first six years of existence. The Bulletin of the Battle Creek Sanitarium and Hospital Clinic, 232-236.

Ashby, W. R. (1952). Design for a brain: The origin of adaptive behaviour. New York: Wiley.

Babkin, B. P. (1949). Pavlov. A biography. Chicago, IL: The University of Chicago Press.

Ban, T., \& McGuigan, F. J. (1987). An overview of Gantt's contribution to science. In F. J. McGuigan \& T. Ban (Eds.), Critical issues in psychology, psychiatry and physiology. A memorial to W. Horsley Gantt (pp. 6-13). New York: Gordon and Breach Science.

Boakes, R.A. (this issue). The impact of Pavlov on the psychology of learning in English-speaking countries.

Brogden, W. J., \& Gantt, W. H. (1942). Intraneural conditioning: Cerebellar conditioned reflexes. Archives of Neurology and Psychiatry, 48, 437-455.

Bykov, K. M. (1957). The cerebral cortex and the internal organs. New York: Chemical Publishing.

Cason, H. (1922a). The conditioned pupillary reaction. Journal of Experimental Psychology, 5, 108-146.

Cason, H. (1922b). The conditioned eyelid reaction. Journal of Experimental Psychology, 5, 153-196.

Catania, A. C., \& Laties, V. G. (1999). Pavlov and Skinner: Two lives in science (An introduction to B. F. Skinner's "some responses to the stimulus 'Pavlov'"). Journal of the Experimental Analysis of Behavior, 72, 455-461.

Coleman, S. R. (1988). Assessing Pavlov's impact on the American conditioning enterprise. Pavlovian Journal of Biological Science, 23, 102-106.

Corson, S. A., \& O’Leary, E. (1987). Schizokinesis and autokinesis. Significant components of biopsychogenic stress reactions and of psychosomatic disorders. In F. J. McGuigan \& T. Ban (Eds.), Critical issues in psychology, psychiatry and physiology. A 
memorial to W. Horsley Gantt (pp. 255-284). New York: Gordon and Breach Science.

Dicara, L. V., \& Miller, N. E. (1967). Instrumental learning of urine formation by curarized rats. Psychonomic Bulletin, 1 , 23-24.

Dewsbury, D. A., \& Bolles, R.C. (1995). The founding of the Psychonomic Society. Part 1. Psychonomic Bulletin and Review, 2, 216-233.

Eysenck, H. J. (1957). The dynamics of anxiety and hysteria. London: Routledge.

Eysenck, H. J. (1967). The biological basis of personality. Springfield, IL: Thomas.

Fernández Guardiola, A. (1997). Las neurociencias en el exilio español en México. México: F.C.E.

Frolov, Y. P. (1937/1965). La actividad cerebral. Estado actual de la teoría de Pavlov. Buenos Aires: Psique.

Furedy, J. J. (2001). An epistemologically arrogant community of contending scholars. A pre-Socratic perspective on the past, present, and future of the Pavlovian Society. Integrative Physiological and Behavioral Science, 36, 5-14.

Gantt, W. H. (1944). Experimental basis for neurotic behavior. Origin and development of artificially produced disturbances of behavior in dogs. New York: Paul B. Hoeber.

Gantt, W. H. (1953). Principles of nervous breakdown in schizokinesis and autokinesis. In E. J. Kempf (Ed.), Comparative conditioned neuroses (pp. 143-163). New York: Annals of the New York Academy of Sciences.

Gantt, W. H. (1959). Application of the conditional reflex method in preventive psychiatry. Diseases of the Nervous System, 30, 30-32.

Gantt, W. H. (1970a). Cardiovascular components of the conditional reflex to pain, food and other stimuli. In W. H. Gantt, L. Pickenhain, \& Ch. Zwingmann (Eds.), Pavlovian approach to psychopathology. History and perspectives (pp. 69-94). Leipzig, Germany: Pergamon Press.

Gantt, W. H. (1970b). The physiological basis of psychiatry: The conditioned reflex. In W. H. Gantt, L. Pickenhain, \& Ch. Zwingmann (Eds.), Pavlovian approach to psychopathology. History and perspectives (pp. 305-327). Leipzig, Germany: Pergamon Press.

Gantt, W. H. (1972). Organ system responsibility, homeostasis and the conditional reflex. Conditional Reflex, 7, 1-10.

Gantt, W. H. (1982). The science of behavior and the internal universe. In J. Eccles (Ed.), Mind and brain. The many-faceted problems (pp. 113-130). Washington: Paragon House.

Giral, F. (1994). Ciencia española en el exilio (1939-1989). El exilio de los científicos españoles. Barcelona: Anthropos.

Gray, J. A. (1964). Pavlov's typology: Recent theoretical and experimental development from the laboratory of B. M. Teplov. Oxford, UK: Pergamon Press.

Hagbloom, S., Warnick, R., Warnick, J. E., Jones, V. K., Yarbrough, G. L., Russell, T. M., Borecky, C. M., McGahhey, R., Powell III, J. L., Beavers, J., \& Monte, E. (2002). The 100 most eminent psychologists of the 20th century. Review of General Psychology, 6, 139-152.
Hamel, I. A. (1919). A study and analysis of the conditioned reflex. Psychological Monographs, 27, 1-66.

Harvey, A. M (1995). W. Horsley Gantt-A legend in his time. Integrative Physiological \& Behavioral Science, 30, 237-243.

Heaton, N. A. (1986). The W. Horsley Gantt papers. Baltimore, MD: The Johns Hopkins University School of Medicine.

Hilgard, E. R. (1933a). Reinforcement and inhibition of eyelid reflexes. Journal of General Psychology, 8, 85-113.

Hilgard, E. R. (1933b). Modification of reflexes and conditioned reactions. Journal of General Psychology, 9, 85-113.

Hull, C. L. (1929). A functional interpretation of the conditioned reflex. Psychological Review, 36, 498-511.

Kline, N. S. (Ed.). (1960). Pavlovian conference on higher nervous activity. New York: Annals of the New York Academy of Sciences.

Lashley, K. S. (1916a). The human salivary reflex and its use in psychology. Psychological Review, 23, 446-464.

Lashley, K. S. (1916b). Reflex secretion of the human parotid gland. Journal of Experimental Psychology, 1, 461-493.

Laties, V. G. (1987). Society for the experimental analysis of behavior: The first 30 years. Journal of the Experimental Analysis of Behavior, 48, 495-512.

Liddell, H. S. (1926). A laboratory for the study of conditioned motor reflexes. American Journal of Psychology, 37, 418-419.

Liddell, H. S. (1953). A comprehensive approach to the dynamics of conditioning neuroses. In E. J. Kempf (Ed.), Comparative conditioned neuroses (pp. 164-170). New York: Annals of the New York Academy of Sciences.

Liddell, H. S. (1956). History and prospects of the behavior farm laboratory at Cornell University. In W. H. Gantt (Ed.), Physiological bases of psychiatry (pp. 243-251). Springfield, IL: Charles C. Thomas.

Livingston, A., Jr., \& Gantt, W. H. (1968). An attempt to condition components of urine formation in dogs. Conditional Reflex, 3 , 241-253.

Lynch, J. J. (1987). W. Horsley Gantt's effect of person. In F. J. McGuigan \& T. Ban (Eds.), Critical issues in psychology, psychiatry and physiology. A memorial to W. Horsley Gantt (pp. 93-106). New York: Gordon and Breach Science.

Mackintosh, N.J. (this issue). Pavlov and ssociationism.

Mateer, F. (1918). Child behavior: A critical and experimental study of young children by the method of conditioned reflexes. Boston, MA: Badger.

Pare, W. P. (1990). Pavlov as a psychophysiological scientist. Brain Research Bulletin, 24, 643-649.

Pavlov, I. P. (1906). The Huxley lecture on the scientific investigation of the psychical faculties or processes in higher mammals. Lancet, 2, 911-915.

Reese, W. G., Peters, J. E., \& Dykman, R. A. (1987). Gantt on Gantt. In F. J. McGuigan \& T. Ban (Eds.), Critical issues in psychology, psychiatry and physiology. A memorial to W. Horsley Gantt (pp. 17-56). New York: Gordon and Breach Science.

Rescorla, R.A. (this issue). Contemporary Study of Pavlovian Conditioning

Ruiz, G., Sánchez, N., \& De la Casa, L. G. (2002a). Pavlovianos en América. Revista de Historia de la Psicología, 23, 467-476. 
Ruiz, G., Sánchez, N., \& De la Casa, L. G. (2002b, August). Pavlov's influence on American psychology: Completing the puzzle. Paper presented at the 21st annual conference of the European Society for the History of the Human Sciences. Barcelona, Spain.

Schlosberg, H. (1928). A study of the conditioned patellar reflex. Journal of Experimental Psychology, 11, 468-494.

Skinner, B. F. (1938). The behavior of organisms: An experimental analysis. New York: Appleton-Century-Crofts.

Skinner, B. F. (1983). A matter of consequences. Part three of an autobiography. New York: Alfred A. Knopf.

Spence, K. W. (1956). Behavior theory and conditioning. New Haven, CT: Yale University Press.

Strelau, J. (1972). The general and partial nervous system types -data and theory. In V. D. Nebylitsyn \& J. A. Gray (Eds.), Biological basis of individual behavior (pp. 62-73). New York: Academic Press.

Todes, D. P. (2002). Pavlov's physiology factory. Experiment, interpretation, laboratory enterprise. Baltimore, MD: Johns Hopkins University Press.
Watson, J. B. (1916). The place of the conditioned reflex in psychology. Psychological Review, 23, 89-116.

Walter, W. G. (1953). The living brain. London: Duckworth.

Wiener, N. (1948). Cybernetics, or control and communication in the animal and the machine. Cambridge, MA: MIT Press.

Windholz, G., \& Lamal, P. A. (1986). Priority in the classical conditioning of children. Teaching of Psychology, 13, 192195.

Wolf, S. G. (1987). W. Horsley Gantt's conceptual contributions to clinical medicine. In F. J. McGuigan \& T. Ban (Eds.), Critical issues in psychology, psychiatry and physiology. A memorial to W. Horsley Gantt (pp. 336-342). New York: Gordon and Breach Science.

Yerkes, R. M., \& Morgulis, S. (1909). The method of Pawlow in animal psychology. The Psychological Bulletin, 6, 257-273.

Received May 19, 2003 Revision received September 24, 2003 Accepted October 7, 2003 